\begin{tabular}{|l|l|l||}
\hline \multicolumn{2}{|c|}{ PublisherInfo } \\
\hline \hline PublisherName & $:$ & BioMed Central \\
\hline \hline PublisherLocation & $:$ & London \\
\hline \hline PublisherImprintName & $:$ & BioMed Central \\
\hline \hline
\end{tabular}

\title{
Wiring up
}

\begin{tabular}{|l|l|l||}
\hline \multicolumn{2}{|c|}{ ArticleInfo } \\
\hline \hline ArticleID & $:$ & 4009 \\
\hline \hline ArticleDOI & $:$ & $10.1186 /$ gb-spotlight-20010309-03 \\
\hline \hline ArticleCitationID & $:$ & spotlight-20010309-03 \\
\hline \hline ArticleSequenceNumber & $:$ & 80 \\
\hline \hline ArticleCategory & $:$ & Research news \\
\hline ArticleFirstPage & $:$ & 1 \\
\hline \hline ArticleLastPage & $:$ & 2 \\
\hline \hline & & RegistrationDate : 2001-03-09 \\
ArticleHistory & $:$ & OnlineDate \\
\hline \hline ArticleCopyright & $:$ & BioMed Central Ltd2001 \\
\hline \hline ArticleGrants & $:$ & \\
\hline \hline ArticleContext & $:$ & 130592211 \\
\hline \hline
\end{tabular}




\section{Jonathan B Weitzman}

Email: jonathanweitzman@hotmail.com

In March 8 Nature, Philip Leighton and colleagues describe a large-scale screen for molecules that guide axons during the development of the nervous system in mice (Nature 2001, 410:174-179). They developed a gene-trap screening method that incorporates elements of the 'secretory trap' technique combined with an axonal marker (placental alkaline phosphatase) whose translation is driven by an IRES (internal ribosome entry site). The method enabled the generation of a large number of mouse lines with diverse patterns of axon labelling in the brain. By comparing the axon tract staining patterns in heterozygous and homozygous mutant mice, Leighton et al were able to characterise axon guidance functions for the semaphorin Sema6A and the Eph receptor Eph4A. The results demonstrate that their gene-trap technique offers a powerful approach to scan the mammalian genome for molecules that regulate axon guidance in a cell-autonomous manner.

\section{References}

1. Nature, [http://www.nature.com/]

2. Capturing genes encoding membrane and secreted proteins important for mouse development.

3. Internal ribosome entry sites and dicistronic RNAs in mammalian transgenesis.

4. University of California Resource of Gene Trap Insertions., [http://socrates.berkeley.edu/ skarnes/ resource.html]

5. The molecular biology of axon guidance.

This PDF file was created after publication. 